\title{
Adding Value: \\ Learning Communities and Student Engagement
}

\author{
Chun-Mei Zhao \\ The Carnegie Foundation for the Advancement of Teaching \\ zhao@,carnegiefoundation.org \\ George D. Kuh \\ Indiana University Center for Postsecondary Research and Planning \\ kuh@,indiana.edu
}




\section{Abstract \\ Adding Value: Learning Communities and Student Engagement}

This study examines the relationships between participating in learning communities and student engagement in a range of educationally purposeful activities of first-year and senior students from 365 four-year institutions. The findings indicate that participating in a learning community is positively linked to engagement as well as student self-reported outcomes and overall satisfaction with college.

Key words: learning communities, college students, student development, student engagement, effective educational practices, integrative learning. 


\section{Adding Value: \\ Learning Communities and Student Engagement}

\section{"I hear and I forget, I see and I remember, I do and I understand." \\ - Confucius, 551 B. C.}

Learning communities are receiving considerable attention by higher education scholars and practitioners. The concept is not new, however. The forerunner of the learning community dates back to the 1920 s and the short-lived "experimental college" program at the University of Wisconsin introduced by Alexander Meiklejohn (Smith, 2001). A variation of this idea emerged once again in the 1960 s with efforts to humanize the learning environment. A contemporary version of the learning community emerged in the late 1980s, supported by the growing recognition that student engagement in educationally purposeful activities inside and outside of classroom is a precursor to high levels of student learning and personal development as well as an indicator of educational effectiveness (ACPA, 1994; Kuh, 1996, 2003; MacGregor, 1991; Study Group, 1984).

Though many forms and definitions of learning communities exist, they have some common academic and social features, such as the same groups of students taking two or more classes together (Brower \& Dettering, 1998). Co-enrolling students in two or more course insures that students see one another frequently and spend a substantial amount of time engaged in common intellectual activities. The experience is even more powerful in terms of learning outcomes when faculty members teaching the common courses structure assignments that require students to apply what they are studying in one course to other courses and assignments. Taken together, these features strengthen the 
social and intellectual connections between students which, in turn, helps build a sense of community among participants (Gabelnick, MacGregor, Matthews, \& Smith, 1990). According to Lenning and Ebbers (1999), learning communities take four generic forms:

1. Curricular learning communities are made up of students co-enrolled in two or more courses (often from different disciplines) that are linked by a common theme;

2. Classroom learning communities treat the classroom as the locus of communitybuilding by featuring cooperative learning techniques and group process learning activities as integrating pedagogical approaches;

3. Residential learning communities organize on-campus living arrangements so that students taking two or more common courses live in close physical proximity, which increases the opportunities for out-of-class interactions and supplementary learning opportunities; and

4. Student-type learning communities are specially designed for targeted groups, such as academically underprepared students, historically underrepresented students, honors students, students with disabilities, and students with similar academic interests, such as women in math, science and engineering. Most learning communities incorporate active and collaborative learning activities and promote involvement in complementary academic and social activities that extend beyond the classroom. Such approaches are linked with such positive behaviors as increased academic effort and outcomes such as promoting openness to diversity, social tolerance, and personal and interpersonal development (Cabrera, et al., 1998; Johnson \& 
Johnson, 1994; Pascarella, et al., 1996; Slavin, 1983; Vogt, 1997; Whitt, et al., 2001). In addition, students who actively participate in various out-of-class activities are more likely to connect with an affinity group of peers, which is important for student retention, success and personal development (Astin, 1984, Pascarella \& Terenzini, 1991; Rendon, 1994, Tinto, 1993).

Integrating these diverse academic and social activities into a meaningful whole is also required to convert the experiences into authentic learning (Chickering, 1974; Newell, 1999). In this way, learning communities operationalize a constructivist approach to knowledge (Cross, 1998), whereby knowledge is not simply "discovered" but is socially constructed. As a result, rather than an authority (instructor) transmitting information, students actively construct and assimilate knowledge through a reciprocal process (Bruffee, 1995; Schon, 1995; Whipple, 1987). As a result, learning is deeper, more personally relevant, and becomes a part of who the student is, not just something the student has.

Learning communities are intentionally structured to help students make two types of connections consistent with this theoretical orientation. The first is encouraging students to connect ideas from different disciplines, which is aided by being co-enrolled in two or more courses (Klein, 2000; MacGregor, 1991). The second connection is through linking students to others through ongoing social interactions afforded by being with the same students for an extended period of time. As a result, students become members of a community focused on academic content which allows them to further develop their identify and discover their voice as well as to integrate what they are learning into their world view and other academic and social experiences. 
Theoretically and conceptually, the learning community appears to be a potentially powerful educational practice. How strong is the evidence for such claims? Previous Research on Effectiveness of Learning Communities

Three strands of research support the use of learning communities (Cross, 1998): (1) developmental research (Baxter-Magolda, 1992; Chickering \& Reisser, 1993; King \& Kitchener, 1994; Piaget, 1964; Perry, 1970), (2) cognitive science (Bransford, Brown, \& Cocking, 2000), and (3) learning outcomes (Matthews, 1993; Pike, 1999; Tinto \& Russo, 1994).

The developmental theory literature encourages educators to design learning environments that both challenge and support students to move to higher levels of intellectual and psychological development. Development is conceptualized as a process whereby students grow and change in response to dealing with novel situations that create a mismatch (Baxter-Magolda, 1992; King \& Kitchener, 1994; Perry, 1970) or induce disequilibrium (Piaget, 1964) into their routine ways of responding. Environments that provide a combination of challenge and support (Chickering \& Reisser, 1993; Sanford, 1962) tailored to students' level of development are recommended to assist students in adapting appropriately to the challenges they encounter (Newman \& Newman, 1998). Interaction with peers from different cultural and disciplinary backgrounds is one way to introduce disequilibrium, thus setting the stage for students to think in different, more complex ways about their experiences.

Done well, the interdisciplinary and interactive nature of learning communities introduces students to complex, diverse perspectives, as contrasted with expecting students to come up with the "right" answer which is characteristic of traditional 
pedagogical approaches such as the large lecture class. The structure of learning communities also promotes critical thinking and contextual learning, skills that are increasingly important in an era of information overload (Bredemeier, 1998; MacGregor, 1991; Shenk, 1997).

Emerging research in cognitive science also stresses the importance of the learning context and developing schema that permit new learning through making connections with what was previously determined to be valid under specific conditions and contexts. The increased opportunities afforded by learning communities for peer learning and interaction allow for the development of richer, complex ways of thinking and knowing so that students learn at a deeper level (Bransford et al., 2000).

Several studies show that participating in learning communities is linked to a variety of desired outcomes of college (Matthews, 1993; McGuen et al., 1996; Pike, 1999; Tinto, 1998; Tinto \& Love, 1995). Tinto and Goodsell (1993) found that first-year students at a large public research university who participated in Freshmen Interest Groups (FIGs) made up of linked courses had higher grades and were more likely to persist when compared with peers who did not experience a FIG. Similarly, Shapiro and Levine (1999) reported that students participating in learning communities were more engaged overall, had higher persistence rates, and evidenced greater gains in intellectual and social development compared with peers who did not participate in learning communities. Tinto and his colleagues (1994) also documented the following benefits of learning communities at two-year colleges: students create their own supportive peer groups that extend beyond the classroom; students become more involved in both in-class and out-of-class activities; students spend more time and effort on academic and other 
educationally-purposeful activities; and students become more actively involved and take more responsibility for their own learning instead of being a passive receiver of information.

Residential learning communities can be especially influential, as they tend to be associated with greater social interaction with peers and extracurricular involvement, higher persistence and graduation rates, and greater gains in critical thinking and reading comprehension (Blimling, 1993; Pascarella, Terenzini, \& Blimling, 1994). These effects may be indirect, as suggested by Pike, Schroeder and Berry (1997) who concluded that membership in residential learning communities enhances overall involvement in educationally purposeful activities, which in turn directly and positively affects indicators of student success (e.g., persistence).

The theoretical and empirical works supporting the efficacy of learning communities are promising. At the same time, much of the published research on learning communities is based on anecdotal evidence or program evaluations (MacGregor, 1991; Matthews, 1993) or from single institutions (MacGregor, personal communication, May 13, 2003; McGuen et al., 1996; Pike, 1999). Though dozens of studies have been conducted at four-year colleges and universities, few are published and, therefore, readily available (MacGregor, personal communication, May 13, 2003). Most of the handful of multiple-institution studies that have been reported are from the twoyear college sector (Tinto \& Love, 1995) or focused on students in specific disciplines such as engineering. 


\section{Purpose}

This study seeks to discover whether participation in a learning community is linked with student success, broadly defined as student engagement in educationally purposeful activities, self-reported gains in a variety of desired outcomes of college, and overall satisfaction with their college experience. We define a learning community simply as a formal program where groups of students take two or more classes together, and may or may not have a residential component. Five research questions guide the study:

1) What is the relationship between participating in a learning community and students' academic performance?

2) What is the relationship between participating in a learning community and student engagement in a range of educationally productive activities, including academic effort (study time), academic integration, active and collaborative learning, interaction with faculty members, diversity-related activities, and the extent to which classes emphasize higher-order thinking?

3) What is the relationship between participating in a learning community and students' perceptions of the degree to which their campus supports their academic and social needs, the quality of academic advising, and satisfaction with their college experience?

4) What is the relationship between participating in a learning community and students' self-reported gains in personal and social development, practical competence, and general education? 
5) What types of students are more and less likely to participate in a learning community?

\section{Methods}

\section{$\underline{\text { Data Source and Instrument }}$}

The data source for this study is the National Survey of Student Engagement (NSSE), an annual survey of first-year and senior students. The NSSE instrument measures the degree to which students participate in educational practices that prior research shows are linked to valued outcomes of college (Chickering \& Gamson, 1987; Kuh, 2001, 2003). Specifically, NSSE assesses student experiences in the following areas: (1) involvement in a range of educationally purposeful in-class and out-of-class activities; (2) amount of reading and writing, (3) participation in selected educational programs, such as study abroad, internships senior capstone courses as well as learning communities, (4) perceptions of the campus environment including the quality of students' relationships with peers, faculty members, and administrators, and (5) student satisfaction with academic advising and their overall collegiate experience. In addition, students estimate their educational, personal, and social growth and development in selected areas since starting college and provide background information, such as their sex, age, race/ethnicity, enrollment status, living arrangements, and major field. The psychometric properties of the survey instrument are well established (Kuh, Hayek, Carini, Ouimet, Gonyea, \& Kennedy, 2001).

The sample is comprised of 80,479 randomly selected first-year and senior students from 365 four-year colleges and universities who completed the NSSE survey in the spring of 2002. The average institutional response rate was $41 \%$. Table 1 shows the 
characteristics of students who say they have, or plan to, participate in a learning community. For example, more first-year students (30\%) than seniors (23\%), more fulltime students (27\%) than part-time students (18\%), and more students of color $35 \%$ Black, 30\% Native American, 32\% Asian, 33\% Latino) than White students (24\%) are involved in learning communities than Table 2 indicates that students at private and public institutions are about equally likely to participate.

[Insert Tables 1 and 2 here]

Using 47 items from the NSSE, we constructed six scales to represent dimensions of student engagement, three measures to gauge quality of campus environment, and three scales to measure student self-reported learning outcomes (Figure 1). Appendix A includes more information about the items contributing to these measures as well as internal scale consistencies (Cronbach's alpha). 
Figure 1

Dependent Measures

Engagement Activities

1. academic effort

2. higher-order thinking skills required in the courses

3. academic integration

4. active and collaborative learning

5. interaction with faculty members

6. diversity-related experiences

Quality of Campus Environment

1. quality of academic advising experiences

2. supportive campus environment (academic and social support, quality of relations with peers, faculty members and administrators)

3. satisfaction with the overall college experience

\begin{tabular}{ll}
\hline Student Outcomes \\
\hline 1. gains in personal and social development \\
2. gains in general education \\
3. gains in practical competence \\
\hline
\end{tabular}




\section{$\underline{\text { Data Analysis }}$}

The analysis was conducted in three steps. First, to answer the first research question we conducted t-tests to compare the entering SAT or ACT scores and selfreported grades of students who participated in the leaning communities with those who did not. It is possible that students who choose to join a learning community are more academically able as reflected by measures of ability, which could account for differences in outcomes that might be associated with learning communities and not necessarily the experience itself. Because grades are highly correlated with academic ability (SAT/ACT scores), we used multivariate ordinary least squares (OLS) regressions to control for the influence of these confounding variables in order to determine the net effect of learning communities on student academic performance.

Second, in order to answer the second, third and fourth research questions we conducted a series of multivariate ordinary least squares (OLS) regressions to determine the relationships between participating in a learning community and student engagement, perceptions of the college environment, and learning and satisfaction outcomes. We controlled for student and institutional characteristics, including enrollment status (fullor part-time), place of residence (on or off campus), age, gender, class, race/ethnicity, SAT/ACT score, major, parent's education, transfer status, Greek affiliation, sector, Carnegie classification, and total undergraduate enrollment. By controlling for students' entering SAT and ACT scores, we can establish whether the effects of the learning community are due to the possibility of self-selection (perhaps learning communities attract more academically able students) or to the distinctive features of the learning community milieu that foster higher levels of student engagement. We computed y- 
standardized coefficients (the unstandardized regression coefficient divided by the pooled standard deviation) to estimate effect sizes for the OLS Models (Greenwald, Hedges, \& Laine, 1996; Light \& Pillemer, 1982; Pascarella, Flowers, \& Whitt, 2001). As suggested by some researchers, we considered an effect size of less than .10 to be substantively trivial, meaning the differences are too small to warrant consideration in making policy decisions (Alexander \& Pallas, 1985; Rosenthal \& Rosnow, 1991). We considered an effect size larger than .10 to be of potential practical import and, thus, worthy of attention.

Finally, to answer the last research question, we employed logistic regression analysis to determine the characteristics of students who participate in a learning community, such as year in school, gender, enrollment status, transfer status, and major field. We examined the odds ratio (Menard, 1995) to identify those student groups that had a higher probability of being in a learning community.

Results

Participating in learning communities is uniformly and positive linked with student academic performance, engagement in educationally fruitful activities (such as academic integration, active and collaborative learning, and interaction with faculty members), gains associated with college attendance, and overall satisfaction with the college experience. In the following sections we describe these positive effects in more detail.

Academic performance. Table 3 shows that students who participated in learning communities had lower entering SAT/ACT scores than their counterparts who did not participate in learning communities. This is true for both first-year and senior students. 
With respect to grades, first-year students in learning communities had lower grades than those without learning community experiences. However, there were no differences in the grades of seniors between those who did and did not have a learning community experience.

To determine if student ability might be affecting their academic performance we first entered into the regression students' entering SAT/ACT scores as a control variable, and then added other student and institutional characteristics to examine the influence of these potentially confounding factors on our study. This analysis indicated that after controlling for these factors there were no differences in the grades of first-year students; however, seniors with a learning community experience had higher grades compared with those who did not participate in a learning community at some point during college. This would suggest that participating in a learning community may have a salutary effect on academic performance.

\section{[Insert Table 3 here]}

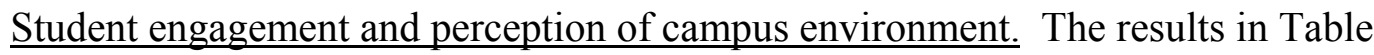
4 indicate that for both first-year and senior students, experience with a learning community is associated with higher levels of academic effort, academic integration, and active and collaborative learning. Similarly, learning communities are positively linked with more frequently interacting with faculty members, engaging in diversity-related activities, and having classes that emphasize higher-order thinking skills. Students in learning communities also were more positive about the quality of academic advising and the degree to which their campus was supportive of their academic and social needs, and generally more satisfied with their college experience. The effect sizes range from .23 to 
.60 for first-year students and .17 to .54 for senior students, indicating that the influence of the learning community experience was substantial. Being in a learning community was strongly linked with active and collaborative learning and interaction with faculty members (effect sizes were larger than .50) for both classes. As indicated by the relative magnitudes of the significant effects, learning communities have stronger effects for firstyear students than for seniors. This is to be expected, as first-year students have the most recent experience with learning communities. At the same time, it is noteworthy that the effects of learning communities persist well into the senior year.

[Insert Table 4 here]

Learning outcomes. Learning communities are also positively associated with student gains in personal and social development, practical competence, and general education. Once again, the effect sizes are substantial, ranging from .36 to .48 for firstyear students and .24 to .40 for senior students. Similarly, first-year students had higher level of gains associated with learning community experiences than seniors across all three general areas.

Who participates in learning communities? Table 5 indicates the types of students (combined first-year and senior students) who are most likely to participate in a learning community. They include native students (contrasted with transfer students), students of color, members of fraternities and sororities, fulltime students, and students in preprofessional majors and those with two or more majors. In addition, first-year students from families with lower levels of parental education and students living on campus are more likely to get involved in learning communities. Among senior students, women were more likely than men to report having been a part of a learning community. 
[Insert Table 5 here]

\section{Limitations}

This study has several limitations. The most significant is the wording of the learning community question on the NSSE survey. The question asks students if they have participated in, or plan to participate in, a learning community before they graduate. Therefore, strictly speaking, we do not know if students had - in fact -- participated in a learning community when they completed the survey, or whether they were planning to do so. This is problematic primarily for first-year students. For this reason, we excluded from the analysis all students who said they were uncertain about whether they would experience a learning community. For example, about $43 \%$ of first-year students indicated they were uncertain. That said, the results are essentially the same for both first-year students - some fraction of whom probably had not yet had a learning community experience even though they may have answered the question in the affirmative -- and for seniors - the vast majority of whom almost certainly did have the experience inasmuch as they were in their final semester of undergraduate study. Thus, despite the ambiguous wording, the results show an overwhelmingly positive effect of participating in learning communities for both first-year and senior students.

The second limitation is related to our inability to distinguish among different types of learning communities. As mentioned earlier, learning communities take different forms and it would be instructive to know if some approaches have more or less desirable effects. However, we cannot do this with the information from the NSSE survey. 
A third limitation relates to the reliability of some of the scales employed in this study. To summarize the large number of survey items, we used 12 measures that have a good deal of conceptual consistency to represent the major academic and social aspects of engagement activities. Two of the scales have marginal Cronbach alpha coefficients -.53 for academic effort and .62 for academic integration. The results associated with these scales should be interpreted with some caution.

Fourth, the gain measures used in this study are based on self-reported data. Students in different learning environments have different learning experiences and the influence of these factors on their perceptions may differ (Pike, 2000). In addition, students may report their gains from college using different baselines depending on their openness to college experiences, a concern that is especially relevant for studies using student self-reported gains (Pascarella, 2001). Therefore, the findings related to gains and satisfaction should be interpreted with this in mind.

Finally, membership in learning communities influences student development in complex ways. As suggested by Pike (2000) and his colleagues (Pike, Schroeder, \& Berry, 1997), learning communities probably do not directly affect student gains; rather, learning communities provide a fertile environment for student growth through engagement with other influential agents of socialization, such as peers and faculty members. Consistent with this rationale, path models or structural equation modeling may have advantages in understanding the effects of learning communities on student engagement, learning, and personal development.

Discussion and Implications 
By and large, the findings from this study tend to corroborate previous research on the value-added effects of participating in learning communities. Learning communities are associated with enhanced academic performance, integration of academic and social experiences, gains in multiple areas of skill, competence, and knowledge, and overall satisfaction with the college experience. Taken together, the results are impressive, especially the substantial effect sizes that favor students who had a learning community experience. These effects remain fairly strong into the senior year, suggesting that introducing students early in their college years to the kinds of educationally purposeful activities often associated with learning communities, such as interacting with faculty members and cooperating with peers on learning tasks, may encourage them to continue these activities throughout college. Given the weight of this and other evidence (e.g., MacGregor, 1991, Matthews, 1993; Pike, 2000; Smith, 2001; Tinto, 1997, 1998, 2000), learning communities qualify to be added to the list of effective educational practices (Chickering \& Gamson, 1988; Education Commission of the States, 1995; Kuh, 2001, 2003).

Given these uniformly positive effects, academic leaders at colleges and universities should seriously consider at least two actions. First, every campus should take stock of how many and what kinds of learning communities are operating and the numbers of different groups of students (e.g., first-year students, men, students of color) who are participating in them. A related step is to determine the optimal number of students that a campus can accommodate with its various forms of learning communities. This is especially important at large, complex institutions where curricular fragmentation 
and social isolation are likely to be great and cross disciplinary learning needs to be encouraged.

Second, efforts should be targeted to creating additional learning communities and attracting students to them, especially those who tend to be underrepresented at the present time. All students should have the chance to benefit from structured efforts that create conditions for connected learning and promote integration of their academic and social experiences. The findings from this study suggest that men, transfer students, and part-time students are less likely to participate in a learning community before they graduate. Individual institutions need to determine whether these national results hold for their campus, and the factors that are operating that may preclude their participating in this educationally rich opportunity. Student affairs professionals, academic advisors, faculty members, and others need to work collaboratively to make sure students are aware the opportunity and recruit students to participate in learning communities.

Third, some forms of learning communities may be more educationally effective than others (Lenning \& Ebbers, 1999). Thus, additional research is needed both at the institution level and across multiple colleges and universities to determine whether some forms of learning communities are more effective than others for various groups of students and for what kinds of outcomes. Linking participation in learning communities with institutional records about student academic progress and other college experiences could yield promising insights into how to more effectively structure other aspects of the college program for certain groups of students. Any efforts to estimate the efficacy of learning communities at the campus level need to take into account both the form and nature of student experiences in the respective learning community as well as the 
outcomes measured and triangulated with a variety of student learning and success measures. What are, for example, the relationships between various forms of learning communities and student persistence, academic performance, and other measures of student development across different groups of students? Jean MacGregor and her colleagues at the National Learning Communities Project at The Evergreen State College may be able to answer some of these questions when they complete their review of the published and fugitive literature related to the evaluation and assessment of learning communities.

\section{$\underline{\text { Caveats }}$}

While the results of this study are impressive, learning communities are not a silver bullet. There are likely limits on their effectiveness. Some students chafe at the prospect of cooperative learning tasks, and some faculty find collaborating with other faculty and staff difficult (Tinto, 1998). In addition, despite the sound theoretical framework on which learning communities are based and the promising evidence from this and other studies, learning communities are complicated phenomena. More work needs to be done to fully understand the features that work best and which forms are more potent than others (Pike, 2000).

Some researchers argue that learning communities, in and of themselves, do not produce positive effects; rather, their effects are probably indirect. That is, learning communities enhance student involvement, which in turn positively affects student success (Pike, 2000). Studies are needed that estimate the direct and indirect effects of learning communities on desired outcomes of college and weigh these against other types of enrichment programs. For example, cooperative education and internships, study 
abroad, and service learning, may well have similar positive effects, if implemented appropriately. As attractive as learning communities appear to be from the results of this study, it would be shortsighted to hitch all efforts to improve undergraduate education to the learning community bandwagon.

\section{Conclusion}

This study explored the relationships between learning communities and student academic performance, engagement in a broad array of educationally purposeful activities, and student learning outcomes. The findings generally corroborate previous research and conceptual work in this area, indicating that participation in some form of learning community is positively related to student success, broadly defined to include enhanced academic performance, integration of academic and social experiences, positive perceptions of the college environment, and self-reported gains since starting college. The effects are somewhat stronger for first-year students. This is to be expected, as they had recently experienced, or were still involved in, the learning community when they completed the survey. The effect sizes for seniors were non-trivial on a number of variables, indicating that the positive influence of learning communities persists throughout the college experience.

These results from four-year colleges and universities coupled with the evidence from the two-year sector empirically confirm that the learning community is an effective educational practice. Undergraduate improvement efforts should include increasing the number of learning community opportunities, adapted to an institution's culture, mission and student characteristics, to increase the chances of success for more students. 


\section{References}

Alexander, K. L. \& Pallas, A. M. (1985). School sector and cognitive performance: When is little a little? Sociology of education, 58(2), 115-128.

American College Personnel Association. (1994). The student learning imperative: Implications for student affairs. Washington, DC.

Astin, A. W. (1984). Student involvement: A developmental theory for higher education. Journal of college student personnel, 25, 297-308.

Baxter-Magolda, M. B. (1996). Epistemological development in graduate and professional education. Review of higher education, 19(3), 283-304.

Blimling (1993). The influence of college residence halls on students. In J. C. Smart (Ed.), Higher education: Handbook of theory and research: Vol. 9 (pp. 248-307). New York: Agathon.

Bredemeier, H. C. (1998). Experience vs. understanding: Understanding yourself in twenty-first century societies. New Brunswick (U.S.A.) and London (U.K.): Transaction.

Bransford, J. D., Brown, A. L., \& Cocking, P. R. (Eds). (2000). How people learn: Brain, mind, experience, and school. Washington, DC: National Research Council/National Academy Press.

Brower, A. A. \& Detting, K. M. (1998, November/December). What is a learning community? Toward a comprehensive model. About campus, 15-21.

Brown, C. S. (1981). Alexander Meilkejohn: Teacher of freedom. Berkeley: Meilkejohn Civil Liberty Institute. 
Bruffee, K. A. (1995). Collaborative learning: Higher education, interdependence, and the authority of knowledge. Baltimore, MD: John Hopkins University Press.

Cabrera, A. F., Nora, A., Bernal, E. M., Terenzini, P. T., \& Pascarella, E. T. (1998, November). Collaborative learning: Preferences, gains in cognitive and affective outcomes, and openness to diversity among college students. Paper presented at the Annual meeting of the Association for the Study of Higher Education, Miami, FL.

Chickering, A.W. (1974). Commuting versus resident students: Overcoming the educational inequities of living off campus. San Francisco: Jossey-Bass.

Chickering, A.W., \& Gamson, Z.F. (1987). Seven principles for good practice in undergraduate education. AAHE bulletin, 39(7), 3-7.

Chickering, A. W. \& Reisser, L. (1993). Education and identity. San Francisco: JosseyBass.

Cross, K. P. (1998, July/August). Why learning communities? Why now? About campus, 4-11.

Education Commission of the States. (1995). Making quality count in undergraduate education. Denver, CO: Education Commission of the States.

Gabelnick, F., MacGregor, J., Matthews, R., \& Smith, B. L. (1990). Learning communities. San Francisco: Jossey-Bass.

Greenwald, R., Hedges, L. V., \& Laine, R. D. (1996). The effect of school resources on student achievement. Review of educational research, 66, 361-396. 
Johnson, D. W. \& Johnson, R. T. (1994). Learning together and alone: Cooperative, competitive, and individualistic learning ( $4^{\text {th }}$ ed.). Englewood Cliffs. NJ: PrenticeHall.

King, P. \& Kitchener, K. (1994). Developing reflective judgment: Understanding and promoting intellectual growth and critical thinking in adolescents and adults. San Francisco: Jossey-Bass.

Klein, T. (2000, July/August). From classroom to learning community: One professor's reflections. About campus, 12-19.

Kuh, G.D. (1996). Guiding principles for creating seamless learning environments for undergraduates. Journal of college student development, 37(2), 135-48.

Kuh, G.D. (2001). Assessing what really matters to student learning: Inside the National Survey of Student Engagement. Change, 33(3), 10-17, 66.

Kuh, G.D. (2003). What we're learning about student engagement from NSSE. Change, 35(2), 24-32.

Kuh, G.D., Hayek, J.C., Carini, R.M., Ouimet, J.A., Gonyea, R.M., \& Kennedy, J. (2001). NSSE technical and norms report. Bloomington, IN: Indiana University Center for Postsecondary Research and Planning.

Lenning, O., \& Ebbers, L. (1999). The powerful potential of learning communities: Improving education for the future. ASHE-ERIC higher education report vol. 26, no. 6. Graduate School of Education and Human Development, George Washington University.

Light, R., \& Pillemer, D. (1982). Numbers and narrative: Combining their strengths in research reviews. Harvard educational review, 52, 1-26. 
MacGregor, J. (1991). What differences do learning communities make? Washington center news, 6, 4-9.

Matthews, R. (1993). Enriching teaching and learning through learning communities. In T. O'Banion (ed.), Teaching and learning in the community college. Washington D. C.: The American Association of Community Colleges.

McGuen, S., et al. (1996). Beacon PAL: Peer-assisted learning project update. New Beacon college outcome research briefs No. 11. Sacramento, CA: American River College, Office of Research and Development. (ERIC Document Reproduction Service No. ED 393517).

Menard, S. (1995). Applied logistics regression analysis (2 $2^{\text {nd }}$ ed.). Thousand Oaks, London, New Delhi: Sage.

Newell, W. H. (1999, May/June). The promise of integrative learning. About campus, 1723.

Newman, B. M. \& Newman, P. R. (1998). Development through life: A psychosocial approach. ( $7^{\text {th }}$ ed.). Washington: Wadsworth.

Pascarella, E. T. (2001). Using student self-reported gains to estimate college impact: A cautionary tale. Journal of college student development, 42(5), 488-92.

Pascarella, E. T., Edison, M., Nora, A., Hagedorn, L.S., \& Terenzini, P.T. (1996). Influences on students' openness to diversity and challenge in the first year of college. Journal of higher education, 67, 174-195.

Pascarella, E. T., Flowers, L. \& Whitt, E. J. (2001). Cognitive effects of Greek affiliation in college: Additional evidence. NASPA journal, 38, 280-301. 
Pascarella, E., \& Terenzini, P. (1991). How college affects students: Findings and insights from twenty years of research. San Francisco: Jossey-Bass.

Pascarella, E. T., Terenzini, P. T., \& Blimling, G. S. (1994). The impact of residential life on students. In C. C. Schroeder \& P. Mable (Eds.). Realizing the educational potential of residence halls (pp. 22-52). San Francisco: Jossey-Bass.

Perry, W. G. Jr. (1970). Forms of intellectual and ethical development in the college years. New York: Henry Holt.

Piaget, (1964). Judgment and reasoning in a child. Totowa, NJ: Littlefield, Adams.

Pike, G. R. (1999).The effects of residential learning communities and traditional residential living arrangements on educational gains during the first year of college." Journal of college student development, 40(3), 269-84.

Pike, G. R. (2000). Assessment measures: Methodological issues in the assessment of learning communities. Assessment update, 12(2), 14-15.

Pike, G., R., Schroeder, C. C., \& Berry, T. R. (1997). Enhancing the educational impact of residence halls: The relationship between residential learning communities and first year college experiences and persistence. Journal of college student development, 38, 609-621.

Rendon, L. I. (1994). Validating culturally diverse students: Toward a new model of learning and student development. Innovative higher education, 19(1), 33-51.

Rosenthal, R. \& Rosnow, R. L. (1991). Essentials of behavioral research: Methods and data analysis (2nd ed.). New York: McGraw Hill.

Sanford, N. (1962). The American college: A psychological and social interpretation of the higher learning. New York, Wiley. 
Schon, D. A. (1995). The new scholarship requires a new epistemology. Change, 27, 27-34.

Shapiro, N. S., \& Levine, J. (Eds.). (1999). Creating learning communities: A practical guide to winning support, organizing for change, and implementing programs. San Francisco: Jossey-Bass.

Shenk, D. (1997). Data smog: Surviving the information glut. San Francisco: HarperEdge. Slavin, R. E. (1983). Cooperative learning. New York: Longman.

Smith, B. L. (2001, Summer/Fall). The challenge of learning communities as a growing national movement. $A A C \& U$ peer review, 4(1).

Study Group on the Conditions of Excellence in American Higher Education (1984). Involvement in learning: Realizing the potential of American higher education. Washington, D.C.: U.S. Dept. of Education, National Institute of Education. (ERIC Document Reproduction Service No. ED246883).

Tinto, V. (1993). Leaving college: Rethinking the causes and cures of student attrition. (2nd ed.). Chicago, IL: The University of Chicago Press.

Tinto, V. (1997). Colleges as communities: Exploring the education character of student persistence. Journal of higher education, 68(6), 599-623.

Tinto, V. (1998). Colleges as communities: Taking research on student persistence seriously. Review of higher education, 21(2), 167-77.

Tinto, V. (2000). What we have learned about the impact of learning communities on students? Assessment update, 12(2), 1-2, 12.

Tinto, V., \& Goodsell, A. (1993). Freshman interest groups and the first year experience: Constructing student communities in a large university. Paper presented at the annual meeting of the College Reading and Learning Association. Kansas City, MO. 
Tinto, V. \& Love, A. G. (1995). A longitudinal study of learning communities at LaGuardia Community College. Washington, DC: Office of Education Research and Improvement. (ERIC Document Reproduction Service No. ED 380178).

Tinto, V. \& Russo, P. (1994). Coordinated studies programs: Their effect on student involvement at a community college. Community college review, 22(2), 16-25.

Vogt, W. P. (1997). Tolerance and education: Learning to live with diversity and difference. Thousand Oaks: Sage.

Whitt, E. J., Edison, M. I., Pascarella, E. T., Terenzini, P. T., \& Nora, A. (2001). Influences on students' openness to diversity and challenge in the second and third years of college. Journal of higher education, 72(2), 172-204.

Whipple, W. R. (1987). Collaborative learning. AAHE bulletin, 40(2), 3-7. 
Table 1.

Characteristics of Students in Learning Communities ${ }^{a}$

\begin{tabular}{|c|c|c|c|c|c|c|}
\hline \multirow[t]{2}{*}{ Student Characteristics } & \multicolumn{2}{|c|}{$\begin{array}{c}\text { Learning } \\
\text { Communities: } \\
\text { Yes }\end{array}$} & \multicolumn{2}{|c|}{$\begin{array}{c}\text { Learning } \\
\text { Communities: } \\
\text { No }\end{array}$} & \multicolumn{2}{|c|}{$\begin{array}{c}\text { Learning } \\
\text { Communities: } \\
\text { Undecided }\end{array}$} \\
\hline & $\mathrm{N}$ & $\%$ & $\mathrm{~N}$ & $\%$ & $\mathrm{~N}$ & $\%$ \\
\hline \multicolumn{7}{|l|}{ Class } \\
\hline First-year students & 11489 & 29.6 & 10797 & 27.9 & 16473 & 42.5 \\
\hline Seniors & 9210 & 22.7 & 26691 & 65.9 & 4610 & 11.4 \\
\hline \multicolumn{7}{|l|}{ Gender } \\
\hline Male & 6617 & 24.4 & 13407 & 49.5 & 7059 & 26.1 \\
\hline Female & 14077 & 27.0 & 24077 & 46.1 & 14020 & 26.9 \\
\hline \multicolumn{7}{|l|}{ Race/Ethnicity } \\
\hline White & 15028 & 24.4 & 30681 & 49.8 & 15869 & 25.8 \\
\hline Black & 1501 & 34.5 & 1614 & 37.1 & 1232 & 28.3 \\
\hline Native American & 122 & 29.5 & 182 & 44.0 & 110 & 26.6 \\
\hline Asian & 1445 & 32.0 & 1649 & 36.6 & 1416 & 31.4 \\
\hline Latino & 1198 & 33.3 & 1337 & 37.2 & 1063 & 29.5 \\
\hline \multicolumn{7}{|l|}{ Age } \\
\hline 19 or younger & 10254 & 29.7 & 9413 & 27.3 & 14811 & 43.0 \\
\hline $20-23$ & 7019 & 24.2 & 18527 & 64.0 & 3418 & 11.8 \\
\hline $24-29$ & 1485 & 21.7 & 4217 & 61.6 & 1139 & 16.6 \\
\hline $30-39$ & 886 & 20.9 & 2579 & 60.8 & 780 & 18.4 \\
\hline $40-55$ & 725 & 21.2 & 2102 & 61.6 & 586 & 17.2 \\
\hline Over 55 & 72 & 25.3 & 161 & 56.5 & 52 & 18.2 \\
\hline \multicolumn{7}{|l|}{ Parent Education } \\
\hline None of the parents graduates from college & 8614 & 26.5 & 15259 & 46.9 & 8686 & 26.7 \\
\hline One parent graduates from college & 5039 & 25.5 & 9530 & 48.3 & 5158 & 26.1 \\
\hline Both parents graduate from college & 6659 & 26.2 & 12097 & 47.6 & 6680 & 26.3 \\
\hline \multicolumn{7}{|l|}{ International Students } \\
\hline International students & 1176 & 30.1 & 1492 & 38.2 & 1237 & 31.7 \\
\hline American students & 19333 & 25.9 & 35689 & 47.8 & 19612 & 26.3 \\
\hline \multicolumn{7}{|l|}{ Transfer Students } \\
\hline Transfer students & 4072 & 21.9 & 11279 & 60.6 & 3256 & 17.5 \\
\hline Native students & 16427 & 27.4 & 25884 & 43.2 & 17579 & 29.4 \\
\hline \multicolumn{7}{|l|}{ Campus Residential Status } \\
\hline On-campus & 10255 & 28.6 & 13501 & 37.7 & 12103 & 33.8 \\
\hline Off-campus & 10250 & 24.0 & 23630 & 55.4 & 8743 & 20.5 \\
\hline \multicolumn{7}{|l|}{ Enrollment Status } \\
\hline Full-time & 18858 & 27.2 & 31498 & 45.4 & 19071 & 27.5 \\
\hline Part-time & 1642 & 18.1 & 5620 & 62.1 & 1792 & 19.8 \\
\hline \multicolumn{7}{|l|}{ Major Fields } \\
\hline Humanities & 2083 & 23.1 & 4640 & 51.5 & 2292 & 25.4 \\
\hline Math \& Sciences & 3828 & 23.2 & 8316 & 50.5 & 4328 & 26.3 \\
\hline Social sciences & 2866 & 22.8 & 6575 & 52.4 & 3108 & 24.8 \\
\hline Pre-professional & 8773 & 29.2 & 13494 & 45.0 & 7735 & 25.8 \\
\hline More than primary major & 513 & 35.7 & 585 & 40.7 & 339 & 23.6 \\
\hline
\end{tabular}

Note. ${ }^{a}$ Membership in learning communities is identified by responding to the question "have you participated in or do you plan to participate in a learning community or some other formal program where groups of students take two or more classes together" with "Yes" or "No." A respondent who answers "undecided" is treated as missing. 
Table 2.

Membership in Learning Communities by Institutional Characteristics

\begin{tabular}{|c|c|c|c|c|c|c|}
\hline \multirow[t]{2}{*}{ Institutional Characteristics } & \multicolumn{2}{|c|}{$\begin{array}{c}\text { Learning } \\
\text { Communities: Yes }\end{array}$} & \multicolumn{2}{|c|}{$\begin{array}{c}\text { Learning } \\
\text { Communities: No }\end{array}$} & \multicolumn{2}{|c|}{$\begin{array}{l}\text { Learning } \\
\text { Communities: } \\
\text { Undecided }\end{array}$} \\
\hline & $\mathrm{N}$ & $\%$ & $\mathrm{~N}$ & $\%$ & $\mathrm{~N}$ & $\%$ \\
\hline \multicolumn{7}{|l|}{ Institutional Sector } \\
\hline Private & 9652 & 25.8 & 17520 & 46.9 & 10219 & 27.3 \\
\hline Public & 11047 & 26.4 & 19968 & 47.7 & 10864 & 25.9 \\
\hline \multicolumn{7}{|l|}{ Carnegie Classification } \\
\hline Doctoral/Research Extensive & 4085 & 26.7 & 7429 & 48.5 & 3801 & 24.8 \\
\hline Doctoral/Research Intensive & 2036 & 26.0 & 3729 & 47.7 & 2058 & 26.3 \\
\hline Master's I and II & 8726 & 27.0 & 15115 & 46.7 & 8536 & 26.4 \\
\hline Baccalaureate-Liberal Arts & 3081 & 22.7 & 6548 & 48.3 & 3928 & 29.0 \\
\hline Baccalaureate-General & 2163 & 26.8 & 3692 & 45.7 & 2222 & 27.5 \\
\hline Baccalaureate-Associate & 608 & 28.7 & 975 & 46.0 & 538 & 25.4 \\
\hline
\end{tabular}


Table 3

Academic Performance of Students Who Did and Did Not Participate in Learning Communities.

\begin{tabular}{|c|c|c|c|c|c|c|c|c|c|c|}
\hline \multirow[b]{2}{*}{ Academic Ability } & \multicolumn{5}{|c|}{ First-year Students } & \multicolumn{5}{|c|}{ Seniors } \\
\hline & $\begin{array}{c}\text { Learning } \\
\text { Communities: } \\
\text { Yes } \\
\text { Mean } \\
\text { (SD) }\end{array}$ & $\begin{array}{c}\text { Learning } \\
\text { Communities: } \\
\text { No } \\
\text { Mean } \\
\text { (SD) }\end{array}$ & $\begin{array}{l}\text { Mean } \\
\text { Diff. }\end{array}$ & Sig. & $\begin{array}{l}\text { Effect } \\
\text { Size }\end{array}$ & $\begin{array}{c}\text { Learning } \\
\text { Communities: } \\
\text { Yes } \\
\text { Mean } \\
\text { (SD) }\end{array}$ & $\begin{array}{c}\text { Learning } \\
\text { Communities: } \\
\text { No } \\
\text { Mean } \\
\text { (SD) }\end{array}$ & $\begin{array}{l}\text { Mean } \\
\text { Diff. }\end{array}$ & Sig. & $\begin{array}{l}\text { Effect } \\
\text { Size }\end{array}$ \\
\hline \multicolumn{11}{|l|}{ Pre-college } \\
\hline SAT/ACT Scores ${ }^{a}$ & $\begin{array}{l}1071 \\
(178)\end{array}$ & $\begin{array}{l}1135 \\
(173)\end{array}$ & -64 & $* * *$ & -0.36 & $\begin{array}{l}1085 \\
(181)\end{array}$ & $\begin{array}{l}1129 \\
(178)\end{array}$ & -44 & $* * *$ & -0.25 \\
\hline \multicolumn{11}{|l|}{ During College } \\
\hline Raw Grades & $\begin{array}{c}3.41 \\
(1.12)\end{array}$ & $\begin{array}{c}3.54 \\
(1.13)\end{array}$ & -0.14 & $* * *$ & -0.12 & $\begin{array}{l}3.74 \\
(.99)\end{array}$ & $\begin{array}{c}3.72 \\
(1.00)\end{array}$ & 0.01 & NS & .01 \\
\hline $\begin{array}{l}\text { Grades Holding Entering } \\
\text { SAT/Act Constant }\end{array}$ & -- & -- & & & & -- & -- & & & \\
\hline & & & .016 & NS & .01 & & & .103 & $* * *$ & .10 \\
\hline $\begin{array}{l}\text { Grades Holding Entering } \\
\text { SAT/ACT, Student, and } \\
\text { Institutional Characteristics } \\
\text { Constant }{ }^{b}\end{array}$ & -- & -- & .033 & NS & .03 & -- & -- & .101 & $* * *$ & .10 \\
\hline
\end{tabular}


Table 4

Effects of Learning Communities on Engagement Activities, Quality of Campus Environment and Selected Learning Outcomes

\begin{tabular}{|c|c|c|c|c|c|c|}
\hline \multirow[b]{2}{*}{ Measure } & \multicolumn{3}{|c|}{ First-year } & \multicolumn{3}{|c|}{ Senior } \\
\hline & $\begin{array}{c}\text { Standardized } \\
\text { Regression } \\
\text { Coefficient }\end{array}$ & Sig. & $\begin{array}{c}\text { Y- } \\
\text { Standardized } \\
\text { Effect size }\end{array}$ & $\begin{array}{l}\text { Standardized } \\
\text { Regression } \\
\text { Coefficient }\end{array}$ & Sig. & $\begin{array}{c}\text { Y- } \\
\text { Standardized } \\
\text { Effect size }\end{array}$ \\
\hline \multicolumn{7}{|l|}{ Engagement Activities } \\
\hline Academic Efforts & 0.157 & $* * *$ & 0.32 & 0.12 & $* * *$ & 0.28 \\
\hline Higher Order Thinking & 0.201 & $* * *$ & 0.40 & 0.151 & $* * *$ & 0.35 \\
\hline Academic Integration & 0.193 & $* * *$ & 0.39 & 0.164 & $* * *$ & 0.38 \\
\hline Active and Collaborative Learning & 0.264 & $* * *$ & 0.53 & 0.237 & $* * *$ & 0.54 \\
\hline Interactions with Faculty & 0.299 & $* * *$ & 0.60 & 0.224 & $* * *$ & 0.51 \\
\hline Diversity Experiences & 0.205 & $* * *$ & 0.41 & 0.156 & $* * *$ & 0.36 \\
\hline \multicolumn{7}{|l|}{ Perception of Campus Environment } \\
\hline Quality of Academic Advising & 0.118 & $* * *$ & 0.23 & 0.076 & $* * *$ & 0.17 \\
\hline Supportive Campus Environment & 0.186 & $* * *$ & 0.37 & 0.141 & $* * *$ & 0.32 \\
\hline Satisfaction & 0.126 & $* * *$ & 0.25 & 0.101 & $* * *$ & 0.23 \\
\hline \multicolumn{7}{|l|}{ Learning Outcomes } \\
\hline Gains in Personal and Social & 0.239 & $* * *$ & 0.48 & 0.175 & $* * *$ & 0.40 \\
\hline Gains in Practical Competence & 0.224 & $* * *$ & 0.45 & 0.157 & $* * *$ & 0.36 \\
\hline General Education Gains & 0.181 & $* * *$ & 0.36 & 0.105 & $* * *$ & 0.24 \\
\hline
\end{tabular}


Table 5

Likelihood That Students Participate in Learning Community.

\begin{tabular}{|c|c|c|c|c|c|c|c|c|}
\hline \multirow{2}{*}{ Predictors } & \multicolumn{4}{|c|}{ First-year Students } & \multicolumn{4}{|c|}{ Seniors } \\
\hline & $\mathrm{B}$ & S.E. & Sig. & Odds Ratio & $\mathrm{B}$ & S.E. & Sig. & Odds Ratic \\
\hline Female & 0.074 & 0.033 & & 1.077 & 0.182 & 0.029 & $* * *$ & 1.200 \\
\hline Age & -0.011 & 0.004 & & 0.989 & 0.004 & 0.002 & & 1.004 \\
\hline Parent Education & -0.074 & 0.019 & $* * *$ & 0.929 & 0.017 & 0.016 & & 1.017 \\
\hline International Students & 0.160 & 0.075 & & 1.174 & 0.144 & 0.065 & & 1.155 \\
\hline Transfer Students & -0.230 & 0.062 & $* * *$ & 0.795 & -0.105 & 0.031 & $* * *$ & 0.900 \\
\hline White & -0.633 & 0.049 & $* * *$ & 0.531 & -0.380 & 0.042 & $* * *$ & 0.684 \\
\hline American Indian & -0.338 & 0.230 & & 0.713 & 0.115 & 0.170 & & 1.122 \\
\hline Asian & 0.047 & 0.080 & & 1.049 & 0.121 & 0.069 & & 1.129 \\
\hline Latino/a & 0.162 & 0.085 & & 1.176 & -0.026 & 0.075 & & 0.974 \\
\hline Greek Affiliation & 0.174 & 0.049 & $* * *$ & 1.191 & 0.261 & 0.037 & $* * *$ & 1.299 \\
\hline Living On-campus & 0.197 & 0.039 & $* * *$ & 1.218 & 0.078 & 0.034 & & 1.081 \\
\hline Enroll Full-time & 0.329 & 0.080 & $* * *$ & 1.389 & 0.476 & 0.042 & $* * *$ & 1.610 \\
\hline Humanity & -0.028 & 0.058 & & 0.972 & 0.053 & 0.048 & & 1.055 \\
\hline Math and Science & -0.077 & 0.050 & & 0.926 & 0.010 & 0.044 & & 1.010 \\
\hline Pre-professional & 0.221 & 0.045 & $* * *$ & 1.248 & 0.445 & 0.037 & $* * *$ & 1.561 \\
\hline Multiple major & 0.360 & 0.106 & $* * *$ & 1.433 & 0.665 & 0.094 & $* * *$ & 1.944 \\
\hline Private & 0.017 & 0.040 & & 1.017 & 0.014 & 0.034 & & 1.014 \\
\hline Enrollment Size & 0.005 & 0.003 & & 1.005 & 0.002 & 0.003 & & 1.002 \\
\hline Doctoral/Research Extensive & -0.262 & 0.058 & $* * *$ & 0.769 & -0.097 & 0.050 & & 0.908 \\
\hline Doctoral/Research Intensive & -0.179 & 0.056 & & 0.836 & 0.010 & 0.048 & & 1.010 \\
\hline Baccalaureate-Liberal Arts & -0.242 & 0.050 & $* * *$ & 0.785 & -0.166 & 0.043 & $* * *$ & 0.847 \\
\hline Baccalaureate-General & -0.099 & 0.056 & & 0.905 & 0.055 & 0.047 & & 1.056 \\
\hline Baccalaureate-Associate & 0.019 & 0.094 & & 1.019 & 0.170 & 0.084 & & 1.185 \\
\hline Constant & 0.309 & 0.153 & & 1.363 & -1.657 & 0.102 & & 0.191 \\
\hline \multicolumn{9}{|l|}{ Model Fit } \\
\hline -2Loglikelihood & \multicolumn{4}{|c|}{24309} & \multicolumn{4}{|c|}{35160} \\
\hline Model Chi-square (df) & \multicolumn{4}{|c|}{$651.1(23)^{* * *}$} & \multicolumn{4}{|c|}{$799.4(23) * * *$} \\
\hline Cox \& Snell $\mathrm{R}^{2}$ & \multicolumn{4}{|c|}{0.035} & \multicolumn{4}{|c|}{0.025} \\
\hline Negelkerke $\mathrm{R}^{2}$ & \multicolumn{4}{|c|}{0.047} & \multicolumn{4}{|c|}{0.037} \\
\hline$\%$ Correct Prediction & \multicolumn{4}{|c|}{$58 \%$} & \multicolumn{4}{|c|}{$75 \%$} \\
\hline
\end{tabular}




\section{Appendix A: Survey Items Contributing to Student Engagement Measures}

Academic Effort (Cronbach's alpha=.53)

- Number of hours per week spending on preparing for class (studying, reading, writing, rehearsing, and other activities related to your academic program)

- The frequency of having worked harder than you thought you could to meet an instructor's standards or expectations during the current school year

- The extent the institution emphasizes spending significant amounts of time studying and on academic work

Higher Order Thinking (Cronbach's alpha $=.80$ )

- During the current school year, the extent coursework emphasized analyzing the basic elements of an idea, experience, or theory

- During the current school year, the extent coursework emphasized synthesizing and organizing ideas, information, or experiences into new, more complex interpretations and relationships

- During the current school year, the extent coursework emphasized making judgments about the value of information, arguments, or methods

- During the current school year, the extent coursework emphasized applying theories or concepts to practical problems or in new situations

Academic Integration (Cronbach's alpha $=.62)$

- The frequency of having worked on a paper or project that required integrating ideas or information from various sources

- The frequency of having included diverse perspectives (difference races, religions, genders, political beliefs, etc.) in class discussions or writing assignments

- The frequency of having put together ideas or concepts from different courses when completing assignments or during class discussions

Active and Collaborative Learning (Cronbach's alpha=.64)

- The frequency of having asked questions in class or contributed to class discussions during the current school year

- The frequency of having made a class presentation during the current school year

- The frequency of having worked with other students on projects during class during the current school year

- The frequency of having worked with classmates outside of class to prepare class assignments during the current school year

- The frequency of having tutored or taught other students (paid or voluntary) during the current school year

- The frequency of having discussed ideas from your readings or classes with others outside of class (students, family members, coworkers, etc.) during the current school year

- The frequency of having participated in a community-based project as part of a regular course

\section{Student Interactions with Faculty Members (Cronbach's alpha=.76)}

- The frequency of having discussed grades or assignments with an instructor during the current school year

- The frequency of having talked about career plans with a faculty member or advisor during the current school year

- The frequency of having discussed ideas from your readings or classes with faculty members outside of class during the current school year

- The frequency of having worked with faculty members on activities other than coursework (committees, orientation, student life activities, etc.) during the current school year

- The frequency of having received prompt feedback from faculty on your academic performance (written or oral) during the current school year 
- Have done or plan to work on a research project with a faculty member outside of course or program requirements before you graduate from your institution

Diversity Experiences (Cronbach's alpha=.66)

- The frequency of having had serious conversations with students of a different race or ethnicity than your own during the current school year

- The frequency of having had serious conversations with students who differ from you in terms of their religious beliefs, political opinions, or personal values during the current school year

- The extent the institution emphasizes encouraging contact among students from different economic, social, and racial or ethnic backgrounds

Supportive Campus Environment (Cronbach's alpha=.77)

- The extent the institution emphasizes providing the support you need to help you succeed academically

- The extent the institution emphasizes helping you cope with your non-academic responsibilities (work, family, etc.)

- The extent the institution emphasizes providing the support you need to thrive socially

- Quality of relationships with other students at your institution

- Quality of relationships with faculty members at your institution

- Quality of relationships with administrative personnel and offices at your institution

Quality of Academic Advising (Single item)

- Evaluate the quality of academic advising you have received at your institution

Gains in Personal and Social Development (Cronbach's alpha=.85)

- The extent your college experience contributed to developing a personal code of values and ethics

- The extent your college experience contributed to understanding people of other racial and ethnic backgrounds

- The extent your college experience contributed to understanding yourself

- The extent your college experience contributed to learning effectively on your own

- The extent your college experience contributed to solving complex real-world problems

- The extent your college experience contributed to voting to local, state, or national elections

- The extent your college experience contributed to improving the welfare of your community

Gains in Quantitative, Analytical, and Work-Related Skills (Cronbach's alpha=.73)

- The extent your college experience contributed to analyzing quantitative problems

- The extent your college experience contributed to acquiring job or work-related knowledge and skills

- The extent your college experience contributed to using computing and information technology

- The extent your college experience contributed to working effectively with others

Gains in General Education (Cronbach's alpha=.80)

- The extent your college experience contributed to writing clearly and effectively

- The extent your college experience contributed to speaking clearly and effectively

- The extent your college experience contributed to acquiring broad general education

- The extent your college experience contributed to thinking critically and analytically 
Satisfaction (Cronbach's alpha=.79)

- How would you evaluate your entire educational experience at this institution?

- If you could start over again, would you go to the same institution you are now attending? 